\title{
Studi Karakteristik Dan Stabilitas Pengemulsi Dari Bubuk Lendir Okra
} (Abelmoschus esculentus)

Study of Okra (Abelmoschus esculentus) Mucilage Powder Emulsifier Properties and Stability

Veliana Lim ${ }^{1 *}$, Leonardus Broto Sugeng Kardono ${ }^{1,2}$, Natania Kam ${ }^{1}$

${ }^{1}$ Fakultas Teknologi Industri, Jurusan Teknologi Pangan, Universitas Pelita Harapan, Tangerang

${ }^{2}$ Badan Pengkajian dan Penerapan Teknologi (BPPT) II, Kementerian Riset dan Teknologi, Jakarta

*Korespondensi dengan penulis (veliana.lim@gmail.com)

Artikel ini dikirim pada tanggal 15 Maret 2015 dan dinyatakan diterima tanggal 5 April 2015. Artikel ini juga dipublikasi secara online melalui www.journal.ift.or.id. Hak cipta dilindungi undang-undang. Dilarang diperbanyak untuk tujuan komersial.

Diproduksi oleh Indonesian Food Technologists ${ }^{\circledR} \bigcirc 2015$ (www.ift.or.id)

\begin{abstract}
Abstrak
Penelitian bertujuan untuk menganalisis sifat fisikokimia Bubuk Lendir Okra (BLO) dan stabilitas emulsi minyak dalam air dengan BLO sebagai pengemulsi. Lendir okra memiliki kemampuan untuk membentuk emulsi yang stabil. Lendir diekstraksi dengan metode ekstraksi cair dan microwave yang kemudian diisolasi dan dikeringkan untuk mendapatkan BLO. Rendemen BLO yang dihasilkan adalah $11,84 \%$. Warna BLO yang dihasilkan adalah coklat kemerahan. Analisis proksimat menunjukkan bahwa BLO didominasi oleh karbohidrat. Analisis FTIR menunjukkan bahwa BLO tersusun dari galaktosa, rhamnosa, dan asam galakturonik. Protein penyusun BLO tersusun atas asam amino hidrofilik dan hidrofobik. Emulsi dengan BLO, stabil dalam berbagai kondisi kekuatan ion $(0-1000 \mathrm{mM})$, suhu (suhu kamar $[R T]-90^{\circ} \mathrm{C}$ ), dan $\mathrm{pH}(2-9)$. Dibandingkan dengan pengemulsi nabati berbasis polisakarida lainnya (Arabic Gum [AG], Guar Gum [GG], dan Xanthan Gum [XG]), daya serap air dan stabilitas emulsi BLO paling tinggi, daya serap minyak BLO tidak berbeda signifikan $(p<0,05)$, dan aktivias emulsi BLO berada di posisi kedua terendah.
\end{abstract}

Kata kunci: emulsi minyak/air, ekstraksi cair, ekstraksi microwave, pengemulsi bubuk lendir okra, stabilitas emulsi.

\section{Abstract}

Okra has been known as its ability to form a stable emulsion. In this study, the physicochemical properties of Okra Mucilage Powder (OMP) and OMP-added-oil-in-water emulsion stability were studied. The mucilage was extracted by using aqueous extraction. Microwave-assisted extraction method was also applied to increase the yield. The obtained mucilage was then isolated and dried to obtain OMP. The yield of OMP was $11.84 \%$ and the colour was redish-brown. Proximate analysis results showed that the OMP was dominated by carbohydrates. FTIR analysis result showed that the OMP was composed of galactose, rhamnose, and galacturonic acid. Protein of OMP consisted of both hydrophilic and hydrophobic amino acids. OMP-added-emulsions were found stable in wide range of ionic strengths (0$1000 \mathrm{mM}$ ), temperatures (room temperature [RT] $-90^{\circ} \mathrm{C}$ ), and $\mathrm{pH}(2-9)$. Compared to other polysaccharide-based emulsifiers (Gum Arabic [AG], Guar Gum [GG], and Xanthan Gum [XG]), the water holding capacity of OMP-added emulsion and its stability was the highest, oil absorption of OMP did not differ significantly $(p<0,05)$, and the emulsion activity OMP was in the second lowest position.

Keywords: aqueous extraction, emulsion stability, microwave-assisted extraction, oil-in-water emulsion, okra mucilage powder emulsifier.

\section{Pendahuluan}

Buah okra (Abelmoschus esculentus L.) atau juga dikenal dengan Ladies Finger merupakan tanaman tropis yang sudah lazim dikonsumsi masyarakat. Potensi lendir okra dalam industri pangan dan farmasi telah banyak dipelajari (Preedy et al., 2011). Lendir okra merupakan hidrokoloid polisakarida rantai panjang dengan berat molekul tinggi dan protein penyusun yang mengandung kedua zat hidrofilik dan hidrofobik. Karakteristik ini menyebabkan lendir buah okra memiliki potensi sebagai agen pengemulsi, pengental dan agen pengikat. Sudah banyak penelitian yang dilakukan mengenai pemanfaatan lendir okra dalam industri obat-obatan sebagai tablet binder yang hemat biaya (Gasendo et al, 2012; Tavakoli et al, 2008; Emeje et al, 2007). Lendir okra sebanyak 4\% $\mathrm{b} / \mathrm{v}$ menunjukan potensinya sebagai tablet binder dalam suspensi parasetamol (Kumar et al., 2009). Penelitian sebelumnya yang dilakukan oleh Dayana \& Hayati (2012) menunjukkan potensi lendir okra sebagai pengemulsi dalam model minuman emulsi minyak/air. Hasil penelitian mereka menunjukan bahwa, emulsi dengan pengemulsi lendir okra lebih stabil daripada emulsi dengan pengemulsi Gum Arabic.

Namun stabilitas emulsi dipengaruhi oleh konsentrasi pengemulsi yang ditambahkan dan kondisi lingkungan seperti kekuatan ion (konsentrasi garam), $\mathrm{pH}$, dan suhu (Shuster, 1985 dan Charoen et al., 2011). Sehingga, pengaruh keempat faktor tersebut terhadap stabilitas emulsi BLO dipelajari dalam penelitian ini.

Gum Arabic, Guar Gum, dan Xanthan Gum merupakan tiga pengemulsi yang biasa digunakan dalam industri pangan (Philips and Williams, 2009; Embuscado, 
2014; Cho and Samuel, 2009). Oleh karena itu, dalam penelitian ini, karakteristik pengemulsi (daya serap minyak, daya serap air, aktifitas emulsi, dan stabilitas emulsi) BLO dibandingkan dengan ketiga pengemulsi tersebut terutama untuk tujuan mengamati potensi BLO sebagai salah satu alternatif pengemulsi nabati.

\section{Materi dan Metode}

Materi

Bahan-bahan yang digunakan dalam penelitian ini adalah buah okra "Bimandiri", Arabic Gum, Guar Gum, Xanthan Gum, minyak goreng, air, pewarna makanan (hijau), larutan buffer $\mathrm{pH} 2-9$, natrium hidroksida $1 \mathrm{M}$, asam klorida $1 \mathrm{M}$, natrium klorida, etil alkohol 96\%, aseton, serta bahan kimia lainnya yang digunakan untuk analisis. Peralatan yang digunakan selama penelitian adalah mixer "Philips", microwave "Sanyo EM-P", kromameter Minolta CR-300, blender kering "Panasonic MXJ1G", water bath, oven "Memmert", vortex, centrifuge "Hettich zentrifugen EBA 20", Siever 80 mesh, termometer, mikroskop "Olympus", serta alat yang digunakan untuk analisis.

\section{Metode}

Penelitian berlangsung selama periode Maret Agustus 2014 dan terbagi menjadi dua tahapan penelitian.

\section{Penelitian Tahap I}

Penelitian tahap I meliputi proses pembuatan BLO dan analisa karakteristik fisikokimia BLO. Analisa fisikokimia meliputi rendemen BLO yang dihasilkan, analisa proksimat (AOAC, 2005), profil asam amino
(HPLC), gugus fungsi (FTIR), dan warnanya (Kromameter Minolta CR-300).

\section{Proses Pembuatan BLO}

Proses pembuatan BLO diawali dengan proses ektraksi lendir okra dari buah okra menggunakan metode ekstraksi cair dan microwave yang dikembangkan oleh Malviya (2011) dan Syah and Shet (2011) dengan modifikasi. Buah okra yang sudah dibersihkan dan diiris direndam selama 4 jam dalam air suling suhu $70^{\circ} \mathrm{C}$ dengan perbandingan 5:1 (air suling: okra). Selanjutnya, rendaman dipanaskan dalam microwave 360 watt, selama 3 menit. Lendir yang terekstrak kemudian dipisahkan dari padatan. Dengan volume yang sama, etil alkohol ditambahkan ke filtrat untuk mengisolasi lendir, kemudian disimpan dalam lemari es selama 3 hari atau sampai isolasi sempurna tercapai. Hasil isolasi berupa endapan kemudian disaring dan dibilas dengan aseton. Endapan dikeringkan semalaman dalam oven $45^{\circ} \mathrm{C}$. Endapan kering kemudian di-blender lalu disaring menggunakan siever 80 mesh. Bubuk lendir yang dihasilkan disimpan dalam wadah kering.

\section{Penelitian Tahap II}

Penelitian ini dilakukan untuk mengetahui pengaruh konsentrasi BLO dan kondisi lingkungan terhadap stabilitas emulsi. Emulsi minyak dalam air (m/a) (air:minyak = 3:1) disiapkan dengan cara mencampurkan fase minyak dan cair dengan menggunakan mixer speed tertinggi selama 10 menit. Fase cair merupakan pengumulsi yang terdispersi dalam larutah penyangga.

Guna melihat potensi BLO sebagai salah satu alternatif pengemulsi nabati, karakteristik pengemulsi

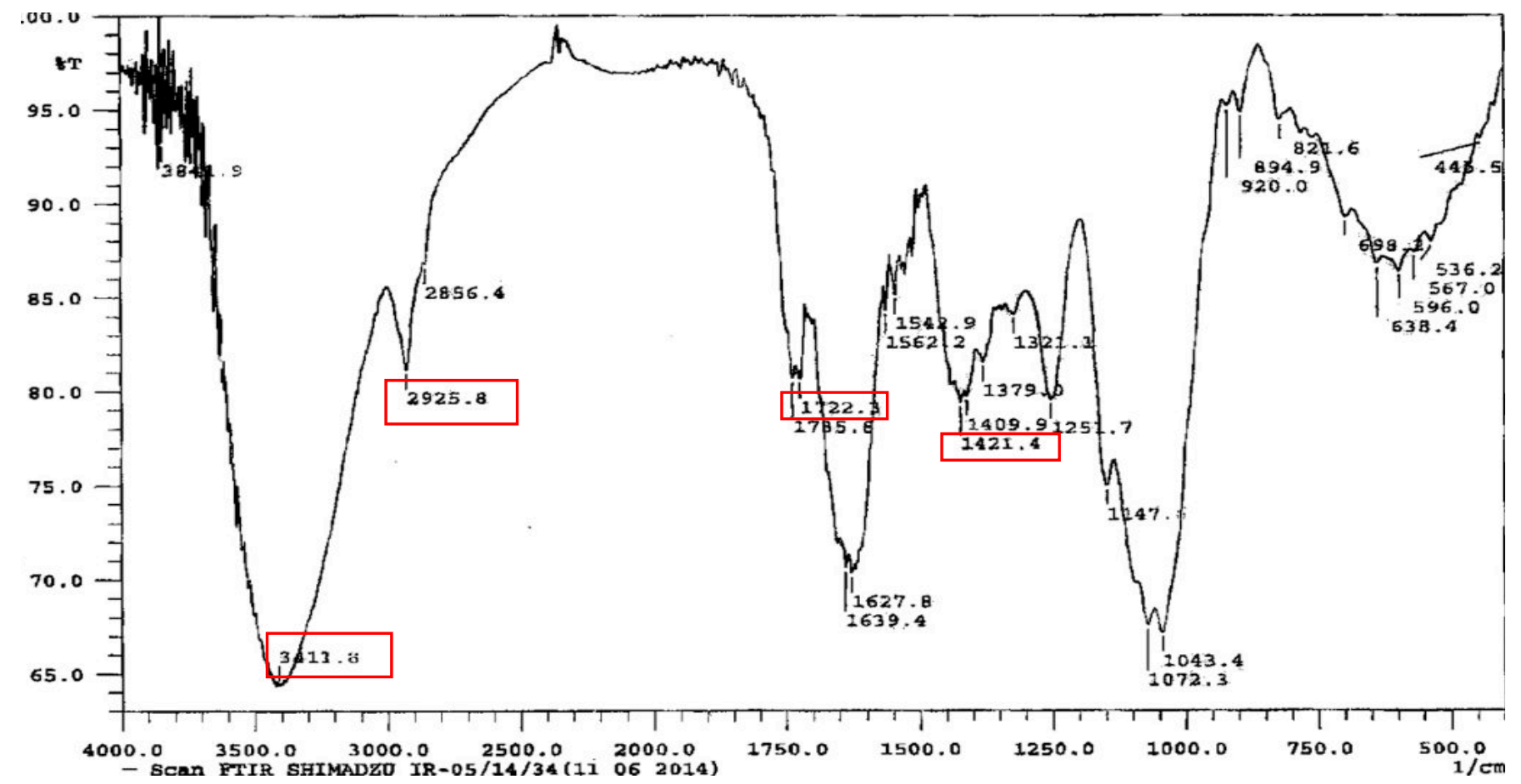

Figur 1. Hasil FTIR Bubuk Lendir Okra 
BLO (daya serap minyak, daya serap air, aktivitas emulsi, dan stabilitas emulsi) dibandingkan dengan 3 pengemulsi nabati berbasis polisakarida lainnya yang sudah umum digunakan dalam industri pangan termasuk Arabic Gum (AG), Guar Gum (GG), dan Xanthan Gum (XG).

Pengaruh Konsentrasi BLO terhadap Stabilitas Emulsi $\mathrm{m} / \mathrm{a}$

Konsentrasi BLO $(0,1-2 \%)$ didispersi dalam larutan penyangga $\mathrm{pH} 7$ kemudian dicampurkan dengan minyak dengan cara yang sudah dijelaskan sebelumnya. Emulsi $\mathrm{m} / \mathrm{a}$ tanpa tambahan BLO juga disiapkan sebagai kontrol/pembanding.

Pengaruh $\mathrm{pH}$, Kekuatan Ion (Konsentrasi Garam), Suhu terhadap Stabilitas Emulsi m/a

Pengaruh pH (2-9), kekuatan ion (0-1000 mM), dan suhu (Suhu Ruang (RT) $-90^{\circ} \mathrm{C}$ ) terhadap stabilitas emulsi secara berurutan dipelajari. $\mathrm{pH}$ diatur dengan menggunakan $\mathrm{NaOH} / \mathrm{HCl}$, garam dilarutkan ke dalam fase cair dengan cara continuous stirring selama 30 menit, sedangkan proses pemanasan emulsi dilakukan dengan cara merendam emulsi dalam water bath suhu ruang - $90^{\circ} \mathrm{C}$ selama 30 menit. Stabilitas emulsi diamati setelah 24 jam penyimpanan dalam suhu ruang. Stabilitas emulsi ditentukan dengan cara menghitung persentase tinggi fase emulsi yang bertahan setelah 24 jam, terhadap tinggi seluruh fase emulsi (Muryani, 2003).

\section{Daya Serap Minyak}

Penentuan daya serap minyak pengemulsi (BLO, AG, GG, dan XG) merujuk pada metode penelitian Thanatcha and Pranee (2011) dengan modifikasi. Lima puluh $\mathrm{mg}$ pengemulsi/mL minyak dicampur selama 1 menit menggunakan vortex. Campuran kemudian dibiarkan selama 30 menit sebelum disentrifugasi 3500 rpm (30 menit). Supernatan dikeluarkan dari tabung, dan berat sampel basah yang tersisa ditimbang. Selisih berat sampel basah dan kering adalah berat minyak yang terserap sampel. Daya serap minyak sampel dinyatakan dalam g minyak/g sampel kering.

\section{Daya Serap Air}

Penentuan daya serap air pengemulsi (BLO, AG, GG, dan XG) merujuk pada metode penelitian Thanatcha and Pranee (2011) dengan modifikasi. Sepuluh mg pengemulsi $/ \mathrm{mL}$ air didispersikan dengan cara continuous stirring selama 15 menit. Campuran kemudian disentrifugasi $3500 \mathrm{rpm}$ (30 menit). Cara penentuan daya serap air ( $\mathrm{g}$ air/g sampel) sama dengan cara penentuan daya serap minyak pada bagian sebelumnya.

\section{Aktifitas Emulsi}

Penentuan aktifitas emulsi pengemulsi (BLO, AG, GG, dan XG) merujuk pada metode penelitian Thanatcha and Pranee (2011) dengan modifikasi. Lima puluh $\mathrm{mg}$ pengemulsi (AG, GG, XG) per mL emulsi dan $10 \mathrm{mg}$ BLO per $\mathrm{mL}$ emulsi disiapkan. Emulsi dibuat dengan mencampurkan minyak dan air (1:1). Masing-masing pengemulsi, minyak, dan air di-mixer selama 1 menit, lalu disentrifugasi 2000rpm selama 10 menit. Volume fase emulsi yang bertahan setelah proses sentrifugasi kemudian dibandingkan dengan volume seluruh fase untuk menentukan persentase aktifitas emulsi dari setiap pengemulsi.

\section{Stabilitas Emulsi}

Stabilitas emulsi dengan pengemulsi BLO dibandingkan dengan pengemulsi $A G, G G$, dan XG. Fase emulsi yang bertahan setelah 24 jam diamati dan persentasi stabilitas emulsi dihitung seperti yang telah dijelaskan pada bagian sebelumnya. Ukuran globula lemak dalam setiap emulsi, sebagai salah satu parameter stabilitas emulsi, ditentukan secara mikroskopis menggunakan mikroskop "Olympus" dengan pembesaran 1000x (Nikzade et al., 2012 dengan modifikasi).

\section{Analisis Statistik}

Data yang diperoleh, dianalisis dengan metode One-Way ANOVA menggunakan SPSS 16.0 Statistic Software. Level signifikan yang ditetapkan sebesar $a=$ 0,05 .

\section{Hasil dan Pembahasan}

Karakteristik Flsikokimia BLO

Rendemen BLO yang dihasilkan sebesar $11,84 \%$. Rendemen yang diperoleh lebih tinggi daripada yang dihasilkan dalam penelitian Malviya (2011) yaitu 9,17\%. Pemanasan singkat dengan bantuan gelombang mikro diterapkan dalam rangka meningkatkan hasil. Shah and Seth (2011) menjelaskan bahwa microwave/gelombang mikro menghancrutkan sel dan jaringan tanaman lebih cepat sehingga memudahkan lendir untuk keluar dari sel dengan cepat.

Analisis proksimat (Tabel 1) menunjukkan bahwa penyusun BLO didominasi oleh karbohidrat. Protein penyusun BLO tersusun oleh asam amino hidrofilik dan hidrofobik (Tabel 2) yang mungkin berkontribusi terhadap fungsi hidrofilk/hidrofobik pengemulsi BLO.

Hasil FTIR (Figur 1) menunjukkan bahwa komponen utama BLO adalah galaktosa, rhamnosa, dan asam galakturonik. Analisis broad peak di $3.411,8 \mathrm{~cm}^{-1}$, merupakan kelompok gula aromatik dengan $\mathrm{O}-\mathrm{H}$ sebagai gugus fungsi utama BLO. Medium peak di $2.925,8 \mathrm{~cm}^{-1}$ menunjukkan adanya $\mathrm{C}-\mathrm{H}$ stretch yang dapat ditemukan di galaktosa dan rhamnosa. Small peak di $1.722,3 \mathrm{~cm}^{-1}$ menunjukan bahwa ada gugus $\mathrm{C}=\mathrm{O}$ stretch yang dapat ditemukan dalam unsur pokok asam galakturonik. Identical small peak di $1.421,4 \mathrm{~cm}^{-1}$ menunjukkan $\mathrm{C}-\mathrm{H}$ bend yang ada di unsur pokok galaktosa dan rhamnosa. Sementara, frekuensi $1200-1000 \mathrm{~cm}^{-1}$ menunjukkan C-O stretch bond yang dapat ditemukan dalam senyawa aromatik galaktosa, rhamnosa, dan asam galakturonik. Hasil FTIR tersebut mirip dengan hasil FTIR dalam 
penelitian yang dilakukan Zaharuddin et al. (2014). Lendir Okra terdiri dari polisakarida kumparan acak yang dibangun oleh $\beta$-D-galaktosa, a-L-rhamnosa, dan $\beta-L$ asam galakturonik.

Warna BLO yang dihasilkan pada penelitian ini adalah coklat kemerahan $\left({ }^{\circ} \mathrm{Hue}=83,02\right)$. Alkurd et al. (2008) menjelasakan bahwa terdapat $1.024 \mathrm{mg}$ tannin per kg bubuk okra kering. Menurut Vaclavik and Christian (2008), tanin (asam tanat) dalam bubuk okra memberikan warna coklat kemerahan seperti warna teh.

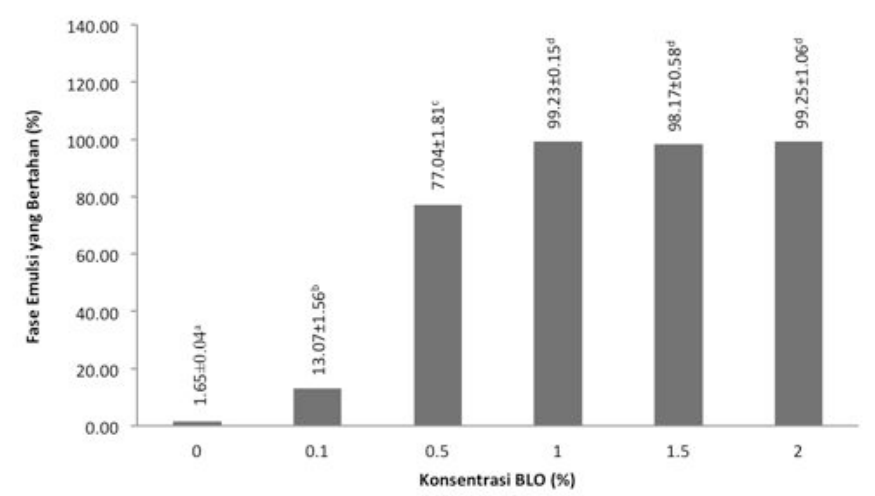

Figur 2. Pengaruh Konsentrasi BLO terhadap Stabilitas Emulsi m/a

Keterangan: superskrip yang berbeda menunjukkan adanya perbedaan yang signifikan $(p \leq 0,05)$

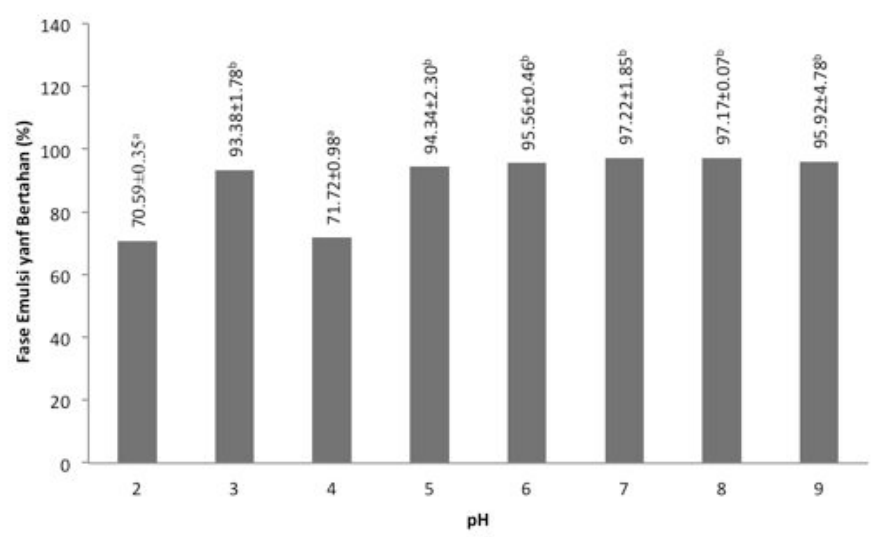

Figur 3 Pengaruh pH terhadap Stabilitas Emulsi m/a Keterangan: superskrip yang berbeda menunjukkan adanya perbedaan yang signifikan $(p \leq 0,05)$

Pengaruh Konsentrasi BLO terhadap Stabilitas Emulsi $\mathrm{m} / \mathrm{a}$

Figur 2 menunjukkan bahwa stabilitas emulsi meningkat seiiring dengan meningkatkan konsentrasi BLO. Pada konsentrasi $1 \%$, stabilitas emulsi mencapai $99,23 \%$. Secara statistik, konsentrasi BLO 1\% keatas tidak memberikan pengaruh yang signifikan terhadap meningkatnya stabilitas emulsi. Hasil yang diperoleh mirip dengan hasil pada penelitian Charoen et al. (2011).

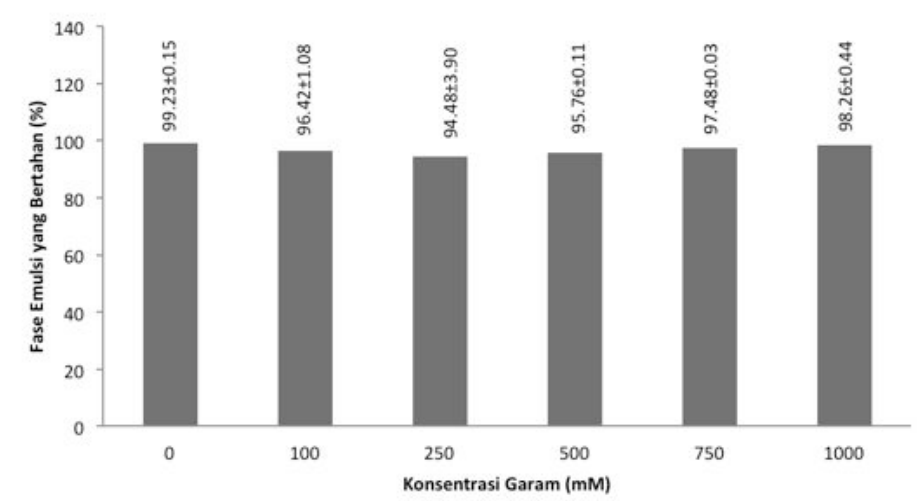

Figur 4 Pengaruh Kekuatan Ion pada Stabilitas Emulsi $\mathrm{m} / \mathrm{a}$

Stabilitas emulsi dapat dipertahankan pada konsentrasi yang lebih tinggi karena ketersediaan pengemulsi yang lebih banyak untuk mencakup interfase minyak-air baru yang terbentuk selama pencampuran (Walstra, 1993; Walstra, 2003; Jafari et al., 2008.). McClements (2005) menjelaskan bahwa, tanpa pengemulsi, stabilitas emulsi tidak dapat bertahan lama. Fase emulsi akan sangat mudah terpisah, membentuk 2 lapisan yang terdiri dari lapisan minyak (massa jenis yang lebih rendah) di bagian atas, dan air (massa jenis lebih tinggi) di bagian bawah.

\section{Pengaruh $\mathrm{pH}$ terhadap Stabilitas Emulsi m/a}

Pengaruh $\mathrm{pH}$ (2-9) terhadap stabilitas emulsi dengan konsentrasi BLO $1 \%$ (paling optimum berdasarkan hasil penelitian pada bagian sebelumnya) ditunjukkan pada Figur 3. Secara statistik, $\mathrm{pH}$ secara signifikan mempengaruhi stabilitas emulsi. Pada $\mathrm{pH} 2$ dan 4, emulsi berada pada kondisi yang paling tidak stabil, sedangkan stabilitas emulsi pada $\mathrm{pH}$ lainnya cukup tinggi yaitu berkisar antara 93,38-97,22\%. Stabilitas tertinggi dicapai pada $\mathrm{pH} 7$, di mana $97,22 \%$ fase emulsi bertahan setelah 24 jam.

Tabel 1. Hasil Analisa Proksimat BLO

\begin{tabular}{cc}
\hline Komposisi & Jumlah $(\%$ Basis Kering $)$ \\
\hline Air & $15,89 \pm 0,07$ \\
Lemak & $3,60 \pm 0,09$ \\
Protein & $12,74 \pm 0,18$ \\
Abu & $10,19 \pm 0,10$ \\
Karbohidrat & $73,47 \pm 0,36$ \\
\hline
\end{tabular}

Menurut (McLean and Kilpatrick, 1997), pengaruh $\mathrm{pH}$ terhadap stabilitas emulsi biasanya berkaitan dengan ionisasi gugus polar komponen active surface. Pada $\mathrm{pH}$ tertentu, interaksi elektrostatik yang saling tolak-menolak muncul dan menggagalkan kohesi interfacial film. Interaksi tolak-menolak yang tinggi mampu mencegah terjadinya interaksi van der Walls dan interaksi hidrofobik, sebagai 2 macam interaksi yang dapat memicu agregasi dan koalisi droplets emulsi. Dengan demikian, stabilitas emulsi dapat dipertahankan (Onsaard et al., 2006). Charoen et al. (2011) menjelaskan bahwa, interaksi 
elektrostatik terutama terjadi karena adanya kandungan protein dalam pengemulsi.

Berdasarkan profil asam amino (Tabel 2), BLO didominasi oleh asam glutamat dan lisin yang merupakan dua asam amino terionisasi (Onsaard et al., 2006). Asam amino terionisasi ini berperan terhadap stabilitas emulsi yang dipengaruhi $\mathrm{pH}$. BLO cukup mampu menjaga stabilitas emulsi pada rentang $\mathrm{pH}$ yang luas (2-9). Penurunan stabilitas emulsi terlihat pada $\mathrm{pH} 2$ dan 4 yang mungkin merupakan titik isoelektrik asam amino pengemulsi BLO. Pada titik ini, protein tidak dapat berinteraksi dengan air sehingga terbentuklah endapan.

Pengaruh Kekuatan Ion (Konsentrasi Garam) terhadap Stabilitas Emulsi m/a

Figur 4 menunjukkan bahwa penambahan garam (0-1000 mM) tidak memberikan pengaruh yang signifikan terhadap stabilitas emulsi. Menurut Chanamai and McClements (2002); Dickinson (2003); McClements (2005), polisakarida, sebagai penyusun utama BLO, umumnya menstabilkan emulsi dengan membentuk interaksi sterik. Oleh karena itu, stabilitas emulsi BLO tidak begitu terpengaruh oleh garam.

Tabel 2 Asam Amino Profil BLO

\begin{tabular}{lclc}
\hline \multicolumn{2}{c}{ Asam Amino Hidrofobik } & \multicolumn{2}{c}{ Asam Amino Hidrofilik } \\
\hline \multicolumn{1}{c}{ Asam amino } & $\begin{array}{c}\text { Jumlah } \\
(\mathrm{ppm})\end{array}$ & Asam amino & $\begin{array}{c}\text { Jumlah } \\
(\mathrm{ppm})\end{array}$ \\
\hline L-Valin & 4868,67 & L-Treonin & 3509,68 \\
L-Prolin & 3542,13 & L-Arginin & 5183,37 \\
L-Alanin & 5024,03 & L-Histidin & 2339,25 \\
L-Phenilalanin & 3151,09 & Glycin & 6085,2 \\
L-Leusin & 5844,82 & L-Serin & 6113,7 \\
L-Isoleusin & 3922,21 & Asam L- & Glutamik \\
& Tidak & Asam L- & 13540,66 \\
L-Methionin & Terdeteksi & Aspartik & 11822,51 \\
Triptofan & 707,79 & L-Lisine HCl & 80618,33 \\
& & L-Sistin & 4722,68 \\
& & L-Tirosin & 2158,07 \\
\hline
\end{tabular}

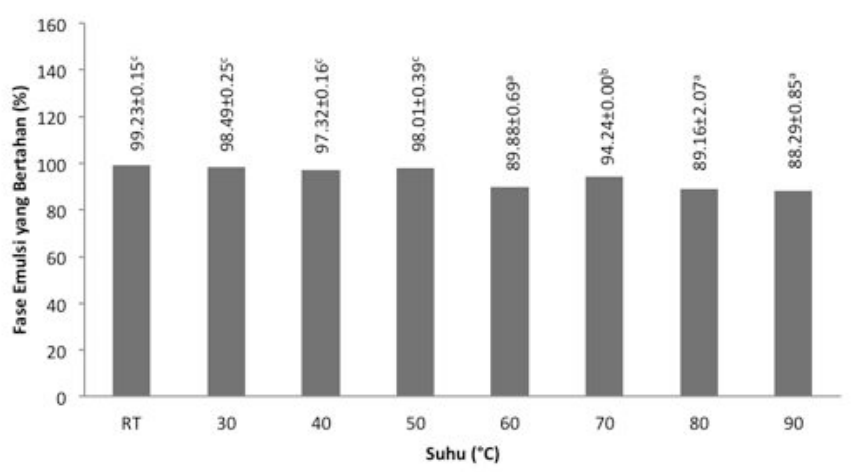

Figur 5 Pengaruh Suhu terhadap Stabilitas Emulsi m/a Keterangan: superskrip yang berbeda menunjukkan adanya perbedaan yang signifikan $(p \leq 0,05), R T=$ Suhu Ruang
Pengaruh Suhu terhadap Stabilitas Emulsi m/a

Figur 5 menunjukan bahwa emulsi dengan BLO tetap memilki kestabilan yang tinggi dalam rentang suhu yang luas (suhu ruang $(\mathrm{RT})-90^{\circ} \mathrm{C}$ ), dengan sedikit penurunan pada suhu diatas $60^{\circ} \mathrm{C}$.

Suhu mempengaruhi stabilitas emulsi terutama emulsi dengan pengemulsi yang mengandung protein seperti BLO. Menurut Charoen et al. (2011), suhu tinggi menyebabkan globular protein terdenaturasi. Denaturasi menyebabkan globular protein terbuka (folded) sehingga gugus non polar terekspos ke fase cair di sekitarnya. Fenomena ini memicu hidrofobisitas permukaan droplets sehingga proses agregasi droplets melaui interaksi hidrofobik yang saling tarik-menarik terjadi (Kim et al., 2005). Namun, karena BLO didominasi oleh polisakarida yang tidak terbuka (unfolded) selama pemanasan, stabilitas emulsi secara umum dapat dipertahankan pada suhu yang tinggi (Charoen et al., 2011).

Tabel 3.Perbandingan Karakteristik Pengemulsi

Parameter

Hasil

Daya Serap Minyak

(g minyak/g pengemulsi)

- BLO (Bubuk Lendir Okra)

- AG (Arabic Gum)

- GG (Guar Gum)

- XG (Xanthan Gum)

Daya Serap Air (g air/g pengemulsi)

- BLO

- $A G$

$-G G$

- XG

Aktivitas Emulsi (\%)

- BLO

- $A G$

$1,35 \pm 0,47$

$0,97 \pm 0,14$

$1,01 \pm 0,07$

$1,02 \pm 0,01$

- $G G$

- XG

$38,68 \pm 0,31^{\mathrm{a}}$

$0,00 \pm 0,00^{\mathrm{d}}$

$19,21 \pm 0,06^{\mathrm{c}}$

$29,65 \pm 0,45^{b}$

Stabilitas Emulsi (\%)

- BLO

- $A G$

$56,45 \pm 2,05^{\mathrm{b}}$

$20,40 \pm 0,85^{\mathrm{a}}$

$65,05 \pm 0,49^{\mathrm{C}}$

$71,30 \pm 2,12^{\mathrm{d}}$

$-G G$

$99,23 \pm 0,15^{\mathrm{a}}$

$48,40 \pm 1,70^{\mathrm{c}}$

$93,90 \pm 1,09^{b}$

- XG

$92,67 \pm 0,19^{b}$

Keterangan: superskrip yang berbeda menunjukkan adanya perbedaan yang signifikan $(p \leq 0,05)$

\section{Daya Serap Minyak}

Perbandingan daya serap minyak BLO, AG, GG, dan XG dapat dilihat pada Tabel 3. Secara statistik, tidak ada perbedaan yang signifikan dalam hal daya serap minyak keempat pengemulsi tersebut. Kemampuan pengemulsi untuk menyerap minyak dipengaruhi oleh struktur penyusunnya. Kemampuan BLO menyerap minyak dipengaruhi oleh matriks polisakarida penyusunnya. Gotlieb and Capelle (2005) menjelaskan bahwa pori-pori pada polisakarida dapat menyerap zatzat termasuk air, etanol, gas/aroma, dan/atau minyak. Semakin banyak jumlah pori-pori polisakarida, semakin 
banyak minyak yang dapat diserap. Daya serap minyak BLO dan ketiga pengemulsi lainnya tidak berbeda secara signifikan, karena penyusun utama keempatnya adalah polisakarida. Molekul-molekul non-polar seperti lemak dan protein juga berperan dalam meningkatkan daya serap minyak sebuah pengemulsi (Mirhosseini and tengah, 2012; Thanatcha and Pranee, 2011). Namun,

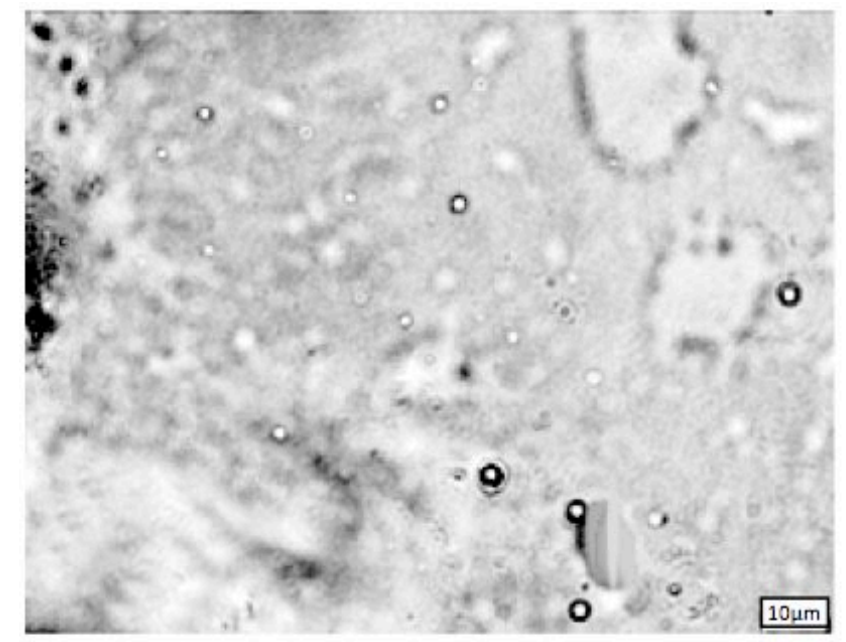

(A)

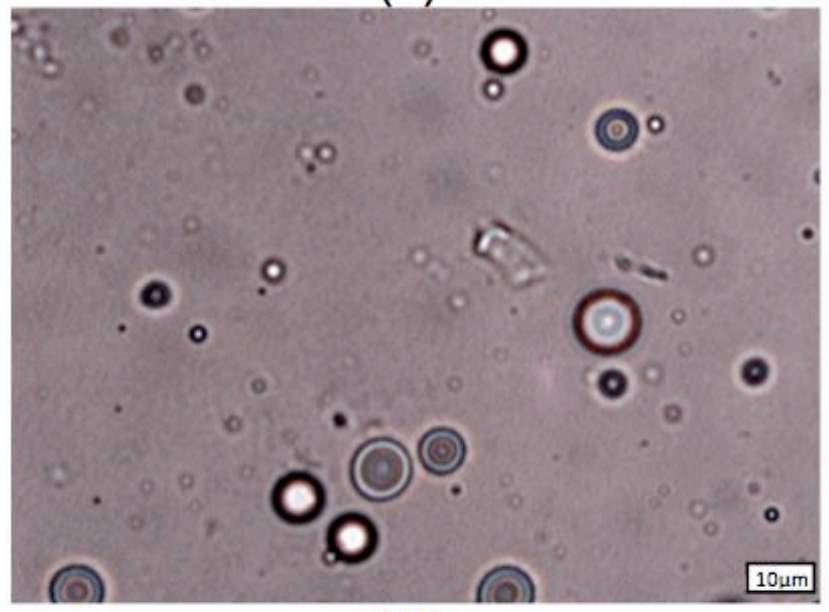

(C) polarnya. Gugus-gugus polar dapat berupa gugus karbonil, hidroksil, amina, karboksil, dan sulfidril.

\section{Aktivitas Emulsi}

Tabel 3 menunjukkan perbandingan aktivitas emulsi dengan BLO dan 3 pengemulsi lainnya. Aktivitas emulsi dengan pengemulsi BLO berada di posisi ketiga

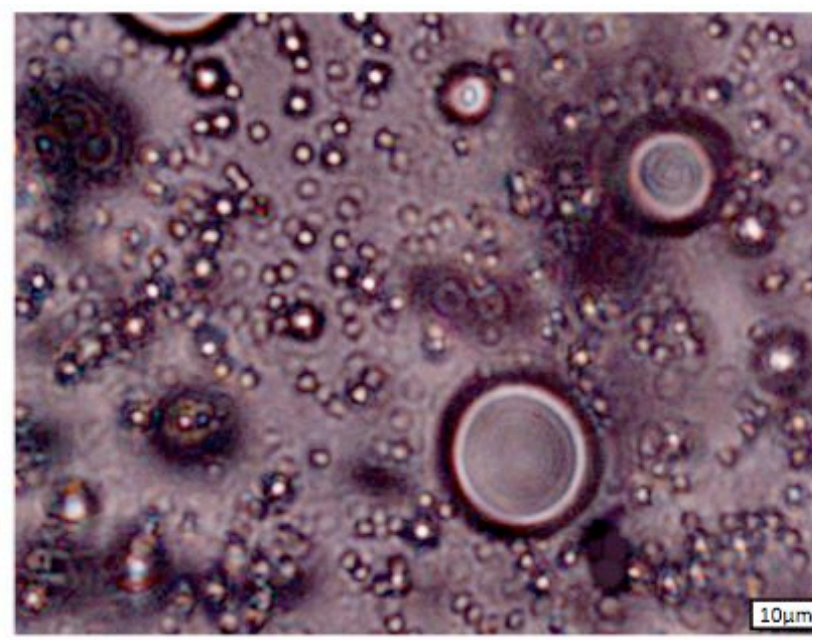

(B)

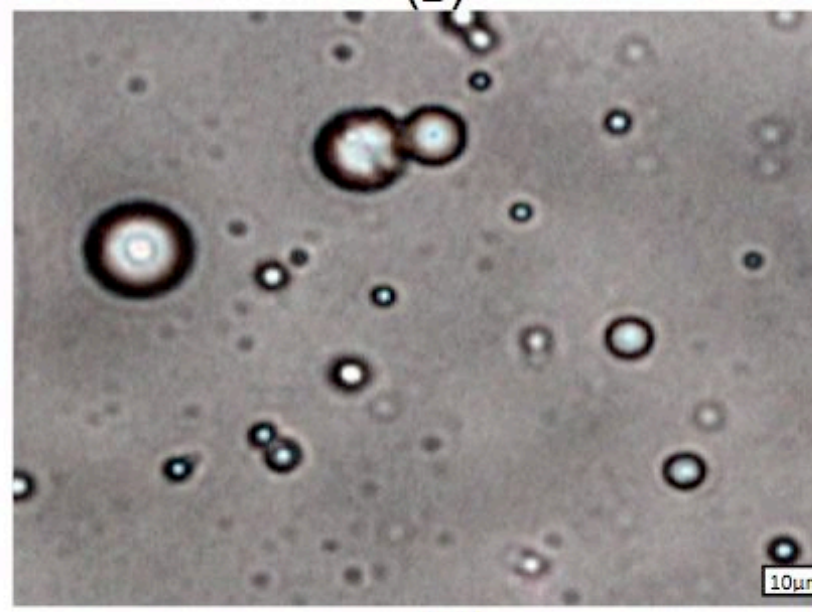

(D)

Figur 6. Globula Lemak Emulsi yang Distabilkan oleh (A) BLO, (B) AG, (C) GG, (D) XG

karena proporsi lemak dan protein dalam BLO relatif kecil, peran keduanya dalam meningkatkan daya serap minyak tidak sebesar polisakarda.

\section{Daya Serap Air}

Daya serap air BLO adalah $38,68 \mathrm{~g}$ air/g BLO. Dibandingkan dengan pengemulsi lain, daya serap air BLO secara signifikan $(p \leq 0,05)$ lebih tinggi dibandingkan XG, GG, dan AG. Menurut Zaharuddin et al. (2014), gugus fungsi hidroksil pada BLO adalah gugus fungsi utama yang bertindak sebagai pengikat air. Kemampuan pengemulsi untuk meningkatkan daya serap air tergantung pada jenis pengemulsi dan jumlah gugus setelah XG dan GG, sementara GA memiliki aktivitas emulsi terlemah. Secara statistik, aktivitas emulsi keempat pengemulsi tersebut secara signifikan $(p \leq 0,05)$ berbeda satu sama lain. Aktivitas emulsi dipengaruhi oleh jenis, kelarutan, konsentrasi, dan formasi protein dari pengemulsi (Ozalp and Karakaya, 2009; Mepba et al., 2008; Aremu et al., 2008). Meski berada di posisi ketiga, konsentrasi BLO (1\%) yang digunakan dalam percobaan ini lebih rendah daripada ketiga pengemulsi lainnya (5\%), sehingga membuat BLO tetap unggul dalam hal mempertahankan aktivitas emulsi. Perlu diketahui bahwa pada bagian ini, konsentrasi $A G$, GG, dan XG yang ditambahkan adalah 5\%, karena konsentrasi $1 \%$ 
pengemulsi saja ternyata tidak dapat mempertahankan emulsi sama sekali.

\section{Stabilitas Emulsi}

Tabel 3 menunjukan bahwa BLO mampu menstabilkan emulsi paling baik di antara yang lain. Pada Figur 6, terlihat bahwa ukuran globula minyak pada emulsi dengan pengemulsi BLO adalah yang terkecil dibandingkan dengan yang lain. Sementara, ukuran globula lemak emulsi dengan pengemulsi AG adalah yang terbesar di antara yang lain. Pembesaran ukuran globula lemak pada setiap emulsi terjadi setelah penyimpanan 24 jam. Ukuran globula lemak emulsi dengan pengemulsi BLO tampak lebih seragam dan lebih kecil dibandingkan dengan pengemulsi lainnya. Ukuran globula lemak juga dapat menjadi parameter stabilitas emulsi. Semakin besar ukuran globula lemak suatu emulsi, maka semakin tidak stabil emulsi tersebut. Pembesaran globula lemak terjadi karena proses flokulasi dan koalisi yang berakhir dengan pemisahan fase atau sedimentasi. Selama flokulasi, droplet-droplet beragregat dan membentuk klaster. Klaster-klaster tersebut menyatu dan membentuk droplet yang lebih besar selama proses koalisi. Pada akhirnya, di bawah pengaruh gravitasi, proses ini menyebabkan terjadinya pemisahan fase dan sedimentasi (Daaou dan Bendedouch, 2012).

Sementara emulsi dengan pengemulsi AG menunjukkan ukuran globula lemak terbesar dibandingkan dengan pengemulsi lainnya. Struktur AG yang kaya akan gugus hidroksil lebih cocok untuk emulsi m/a yang rendah lemak (Mirhosseini dan Amid, 2012). Ukuran globula lemak emulsi dengan pengemulsi $X G$ dan GG lebih kecil dari AG, tetapi lebih besar dari BLO. Keduanya dapat membentuk emulsi yang terlihat seperti gel yang kental, yang mungkin membantu mencegah globula lemak untuk menyatu. Dengan membentuk emulsi yang seperti gel yang padat, pengemulsi tersebut dapat mempertahankan stabilitas emulsi dengan baik (McKetta, 1999 dan Chudzikowski, 1971).

\section{Kesimpulan dan Saran}

Kesimpulan

Berdasarkan hasil penelitian yang diperoleh, BLO dapat mempertahankan stabilitas emulsi bahkan pada konsentrasi yang relatif rendah. BLO juga dapat mempertahankan stabilitas emulsi cukup baik dalam berbagai kondisi lingkungan yang berbeda $(\mathrm{pH}$, konsentrasi garam, dan suhu). Karakteristik pengemulsi BLO juga sebanding dengan pengemulsi komersial lainnya. Dengan demikian, dapat disimpulkan bahwa BLO memiliki potensi yang tinggi sebagai alternatif pengemulsi nabati pada industri pangan.

\section{Saran}

Beberapa saran yang dapat diberikan adalah, meneliti metode ekstraksi BLO untuk mendapatkan rendemen yang lebih tinggi, mencari metode pencampuran terbaik termasuk durasi pencampuran untuk menjaga stabilitas emulsi lebih lama dan membentuk globula lemak yang lebih kecil (mikroemulsi) juga dapat dipelajari. Karena BLO memiliki potensi besar sebagai alternative pengemulsi nabati, BLO dapat dicoba untuk diterapkan ke beberapa produk pangan untuk melihat pengaruh penambahan BLO terhadap penerimaan sensori.

\section{Ucapan Terima Kasih}

Penelitian ini disponsori oleh PT Indofood Sukses Makmur Tbk dalam kerangka Program Indofood Riset Nugraha 2014/ 2015

\section{Daftar Pustaka}

(NARI), National Agricultural Research Institute. 2003. Okra - Postharvest Care and Market Preparation. Ministry of Fisheries Crops and Livestock, and New Guyana Marketing Corporation (NGMC), Georgetown.

Agoha, E. E. C. Biomaterials from Periwinkle Shells: Composition and Functional Properties. 5.

Alkurd, Ref'at A., Hamed R. Takruri, dan Heba Al-Sayyed. 2008. Tannin Contents of Selected Plants Used in Jordan. Jordan Journal of Agricultural Science 4(3).

Aremu, M. O., Olaofe, O., Akintayo, E. T., dan Adeyeye, E. I. 2008. Foaming, Water Absorption, Emulsification and Gelation Properties of Kersting's Groundnut (Kerstingiellageocarpa) and Bambara Groundnut (Vigna subterranean) Flours as Influenced by Neutral Salts and Their Concentrations. Journal of Nutrition, 7(1), 194-201.

Association of Official Analytical Chemists (AOAC). 2005. Official Methods of Analysis of The Association of Analytical Chemists. AOAC, Inc, Virginia.

Chanamai, R., dan D. J McClements. 2002. Comparison of Gum Arabic, Modified Starch, and Whey Protein Isolate as Emulsifiers: Influence of $\mathrm{Ph}, \mathrm{CaCl}_{2}$ and Temperature. Journal of Food Sciece 67(1): 120-5.

Charoen, Ratchanee, Anuvat Jangchud, Kamolwan Jangchud, Thepkunya Harnsilawat, Onanong Naivikul, dan David Julian McClements. 2011. Influence of Biopolymer Emulsifier Type on Formation and Stability of Rice Bran Oil-in-Water Emulsions: Whey Protein, Gum Arabic, and Modified Starch." Journal of Food Science 76, (1): E165 - E172.

Cho, Susan Sungsoo, dan Priscilla Samuel. 2009. Fiber Ingredients: Food Applications and Health Benefits. CRC Press, Boca Raton.

Chudzikowski, R. J. 1971. Guar Gum and Its Applications. J. Soc. Cosmet. Chem 22: 43-60.

Daaou, M. dan D. Bendedouch. 2012. Water pH and surfactant addition effects on the stability of an Algerian crude oil emulsion. Journal of Saudi Chemical Society 16: 333 - 337. 
Dayana, T.Z. Tengku Nur, dan I. Nor Hayati. 2012. Properties and Stability of Model Beverage Emulsion as Affected by Okra Mucilage. Journal of Sustainability Science and Management p. 563 570.

Dickinson, E. 2003. Hydrocolloids at Interfaces and the Influence on the Properties of Dispersed Systems. Food Hydrocolloid 17 (1): 25 - 39.

Embuscado, Milda E. 2014. Functionalizing Carbohydrates for Food Applications. DEStech Publications, Inc, Pennsylvania.

Emeje, M. O., C. Y. Isimi, dan O. O. Kunle. 2007. Evaluation of Okra Gum as a Dry Binder in Paracetamol Tablet Formulations. J. Pharmaceutical Science (1): 15 - 22.

Gasendo, Cherie D., Julmarie Claire C. Pascua, dan Clair J. Supangan. 2012. Cost-Effective Analysis of the Extracted Mucilagenous Substance of Okra (Hibiscus Esculentus) and Corn Starch as Tablet Binders. Journal of Pharmacy 3.

Gotlieb, K. F. dan A. Capelle. 2005. Starch Derivatization: Fascinating and Unique Industrial Opportunities. Wageningen Academic Pubilshers, Netherlands.

Jafari, SM, E. Assadpoor, Y.H. He, dan B. Bhandari. 2008. Re-Coalescence of Emulsion Droplets During High-Energy Emulsification. Food Hydrocolloid 22 (7): 1191-202.

Kim, H.J., E. A. Decker, dan D. J McClements. 2005. Influence of Protein Concentration and Order of Addition on Thermal Stability of Beta-Lactoglobulin Stabilized N Hexadecane Oil-in-Water Emulsions at Neutral pH. Langmuir 21(1): 134-9.

Kumar, Ravi, Patil M.B., Patil S.R., dan Paschapur M.S. 2009. Evaluation of Abelmoschus esculentus Mucilage as Suspending Agent in Paracetamol Suspension. International Journal of Pharm. Tech 1(3): 658 - 665.

Malviya, Rishabha. 2011. Extraction Characterization and Evaluation of Selected Mucilage as Pharmaceutical Excipient. Polimery w Medycynie 41(3).

McClements, D.J. 2005. Food Emulsions: Principles, Practices, and Techniques. 2nd Ed. CRC Press, Boca Raton.

McKetta, J. J. J. 1999. Encyclopedia of Chemical Processing and Design (Vol. 67). Marcel Dekker, Inc, New York.

McLean, J. D., dan P. K. Kilpatrick. 1997. Effects of Asphaltene Aggregation in Model HeptaneToluene Mixtures on Stability of Water-in-Oil Emulsions. Journal of Colloid and Interface Science 196: 23 - 34.

Mepba, H., Achinewhu, S., dan Ademiluyi, T. 2008. Solubility, Emulsion And Foaming Properties Of Coconut (CocosNucifera) Protein Concentrates. African Journal of Food Agriculture Nutrition and Development 8(2), 170 - 191.
Mirhosseini, H. dan Tabatabaee Amid. 2012. Emulsifying activity, particle uniformity and rheological properties of a natural polysaccharide-protein biopolymer from durian seed." Food Biophysics 7:317-328.

Muryani, Dina. 2003. Stabilitas Emulsi Cloudifier Pada Jus Jeruk Pontianak. Universitas Pelita Harapan, Tangerang.

Nikzade.V., M. Mazaheri T., dan M. Saadatmand-Tarzjan. 2012. Optimization of Low Cholesterole-Low Fat Mayones Formulation: Effect of Using Soy Milk and Some Stabilizer by a Mixture Design Approach. Journal of Food Hydrocolloids 28: 344-452.

Onsaard, Ekasit, Manee Vittayanont, Sukoncheun Srigam, dan D. Julian McClements. 2006. Comparison of Properties of Oil-in-Water Emulsions Stabilized by Coconut Cream Proteins with Those Stabilized by Whey Protein Isolate. Food Research International 39: 78 - 86.

Özalp, B., dan Karakaya, M. 2009. Determination of some functional and technological properties of octopus (Octopus culgaris C.), Calamary (Illex coindetti V.). Mussel (Mytilus galloprovincialis L.) and Cuttlefish (Sepia officinalis L.) meats. Journal of Fisheries Science, 3(4), 275 - 284.

Philips, G. O. dan P. A. Williams. 2009. Handbook of Hydrocolloids. Woodhead Publishing Limited, Cambridge.

Preedy, Victor R., Ronald R. V., dan Vinood B. P. 2011. Nuts and Seeds in Health and Disease Prevention. Elsevier, London.

Shah, Biren. N., dan Avinash. K. Seth. 2011. Microwave Assisted Isolation of Mucilage from the Fruits of Abelmoschus esculentus. Journal For Drugs and Medicines 3(1): 54 - 57.

Tavokoli, N, N.Ghassemi Dehkordi, R.Teimouri, dan H. Hamishehkar. 2008. Characterization and Evaluation of Okra Gum as a Tablet Binder. Journal of Natural Pharmaceutical Products 3(1): 33 - 38.

Thanatcha, R., dan A. Pranee. 2011. Extraction and Characterization of Mucilage in Ziziphus Mauritiana Lam. International Food Research Journal 18: 201212.

Vaclavik, Vickie, dan Elizabeth W. Christian. 2008. Essentials of Food Science. Springer Science \& Business Media, New York.

Walstra, P. 1993. Principles of Emulsion Formation. Chemical Engineering Science 48: 397-436.

Walstra, P. 2003. Physical Chemistry of Foods. Marcel Dekker, New York.

Zaharuddin, Nurul Dhania, Mohamed Ibrahim Noordin, dan Ali Kadivar. 2014. The Use of Hibiscus Esculentus (Okra) Gum in Sustaining the Release of Propranolol Hydrochloride in a Solid Oral Dosage Form. BioMed Research International 2014. 